\begin{tabular}{|c|c|c|c|c|}
\hline \multirow{3}{*}{$\begin{array}{l}\text { 2. ECN Category } \\
\text { (mark one) } \\
\text { Supplemental } \\
\text { Direct Revision } \\
\text { Change ECN } \\
\text { Temporary }\end{array}$} & \multicolumn{2}{|c|}{$\begin{array}{l}\text { 3. Originator's Name, Organization, MSIN, } \\
\text { and Telephone No. } \\
\text { A. L. Shord, 8C410, H5-49, } \\
376-1990\end{array}$} & $\begin{array}{l}\text { 4. Use Required? } \\
{[] \text { Yes }[X] \text { No }}\end{array}$ & $\begin{array}{l}\text { 5. Date } \\
\text { January 20, } 1997\end{array}$ \\
\hline & \multicolumn{2}{|c|}{$\begin{array}{l}\text { 6. Project Title/No./Work Order No. } \\
\text { TWRS Privatization Phase I Site } \\
\text { Development/Project W-505/D633A }\end{array}$} & $\begin{array}{l}\text { 7. Bldg./Sys./Fac. No. } \\
\text { TWRS }\end{array}$ & $\begin{array}{l}\text { 8. Approval Designator } \\
\text { NA (see 14b } \\
\text { below) }\end{array}$ \\
\hline & \multicolumn{2}{|c|}{$\begin{array}{l}\text { 9. Document Numbers Changed by this ECH } \\
\text { (includes sheet no. and rev.) } \\
\text { WHC-SD-WM-DRD-013, Rev. O }\end{array}$} & $\begin{array}{l}\text { 10. Related ECH Ho(s). } \\
\text { NA }\end{array}$ & $\begin{array}{c}\text { 11. Related PO No. } \\
\text { NA }\end{array}$ \\
\hline \multirow{2}{*}{$\begin{array}{l}\text { 12a. Modification Hork } \\
\text { [] Yes (fill out Blk. } \\
12 \mathrm{~b}) \\
{[X] \text { No (NA Blks. 12b, }} \\
12 c, 12 d)\end{array}$} & \multirow[t]{2}{*}{$\begin{array}{l}\text { 12b. Work Package } \\
\text { No. } \\
\text { NA }\end{array}$} & $\begin{array}{l}\text { 12c. Modification Work Complete } \\
\text { NA }\end{array}$ & \multicolumn{2}{|c|}{$\begin{array}{l}\text { 12d. Restored to Original Condi- } \\
\text { tion (Temp. or Standby ECN only) } \\
\text { NA }\end{array}$} \\
\hline & & $\begin{array}{c}\text { Design Authority/Cog. Engineer } \\
\text { Signature \& Date }\end{array}$ & \multicolumn{2}{|c|}{$\begin{array}{c}\text { Design Authority/Cog. Engineer } \\
\text { Signature \& Date }\end{array}$} \\
\hline \multicolumn{5}{|c|}{$\begin{array}{l}\text { 13a. Description of change Design Baseline Document? [] Yes [X] No } \\
\text { Revised to include construction power and water. Deleted rail modifications. Added } \\
\text { mitigation of loss of mature sage-steppe habitat destroyed by the site development } \\
\text { work. Editorial changes made. Document title changed from "TWRS Privatization Phase } 1 \\
\text { Roads \& Rails System Modifications \& Site Development Design Requirements Document" to } \\
\text { "TWRS Privatization Phase I Site Development Design Requirements Document". Document } \\
\text { number changed from WHC-SD-WM-DRD-013 to HNF-SD-WM-DRD-013. }\end{array}$} \\
\hline \multirow{2}{*}{\multicolumn{5}{|c|}{$\begin{array}{llllllll}\text { 14a. Justification (mark one) } & & & & & \\
\text { Criteria Change } & {[X]} & \text { Design Improvement } & {[]} & \text { Environmental } & {[]} & \text { Facility Deactivation [] } \\
\text { As-Found } & {[]} & \text { Facilitate Const } & {[]} & \text { Const. Error/Omission } & {[]} & \text { Design Error/Omission [] }\end{array}$}} \\
\hline & & & & \\
\hline \multicolumn{5}{|c|}{$\begin{array}{l}\text { 14b. Justification Details } \\
\text { Revision was required to incorporate the results of FY } 1996 \text { engineering studies that } \\
\text { further defined the TWRS Phase I Privatization Site Development work scope. ESQ and } \\
\text { involved PHMC contractor review of the revisions were requested via EDT } 606384 \text { with } \\
\text { comments subsequently incorporated into the document. DOE-RL comments on the PHMC } \\
\text { approved Rev. I document were requested via EDT } 606354 \text { with comments incorporated. } \\
\text { Review responses/comments are contained in the project file. }\end{array}$} \\
\hline \multicolumn{5}{|c|}{$\begin{array}{l}\text { 15. Distribution (include name, MSIN, and no. of copies) } \\
\text { See Distribution Sheet }\end{array}$} \\
\hline
\end{tabular}




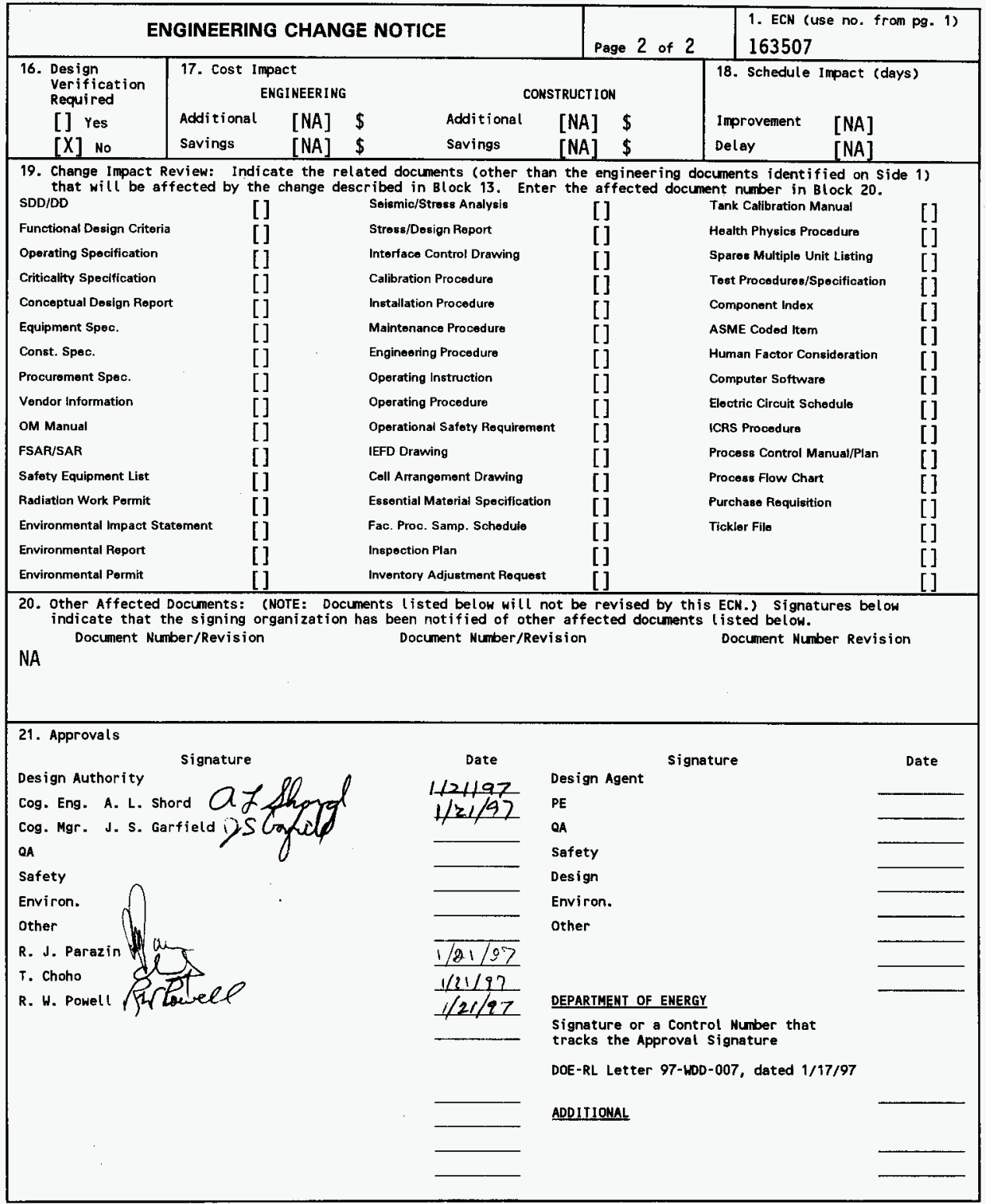




\title{
TWRS PRIVATIZATION PHASE I SITE DEVELOPMENT DESIGN REQUIREMENTS DOCUMENT
}

\author{
A. L. Shord \\ Numatec Hanford Corporation, Richland, WA 99352 \\ U.S. Department of Energy Contract DE-AC06-96RL13200 \\ EDT/ECN: 163507 \\ Org Code: $8 \mathrm{C} 410$ \\ UC: 721 \\ Charge Code: D633A \\ B\&R Code: EW3130000 Total Pages: 26
}

Key Words: TWRS Privatization Phase I, privatization site development, privatization design requirements, grout site

Abstract: The DOE-RL is pursuing a strategy of hiring private contractors for treatment of Hanford Site tank wastes. This strategy is called 'privatization' and includes design, permitting, construction, operation and deactivation of facilities for tank waste treatment. The TWRS Privatization Infrastructure Project consists of several subprojects which will provide key services needed to support the privatization mission. This document identifies the design requirements for the site development sub-project, including construction power and water and road modifications. It will be used in development of the project's conceptual design.

\footnotetext{
TRADEMARK DISCLAIMER. Reference herein to any specific commercial product, process, or service by trade name, trademark, manufacturer, or otherwise, does not necessarily constitute or imply its endorsement, recommendation, or favoring by the United States Government or any agency thereof or its contractors or subcontractors.
}

Printed in the United States of America. To obtain copies of this document, contact: WHC/BCS Document Control Services, P.O. Box 1970, Mailstop H6-08, Richland WA 99352, Phone (509) 372-2420; Fax (509) 376-4989.
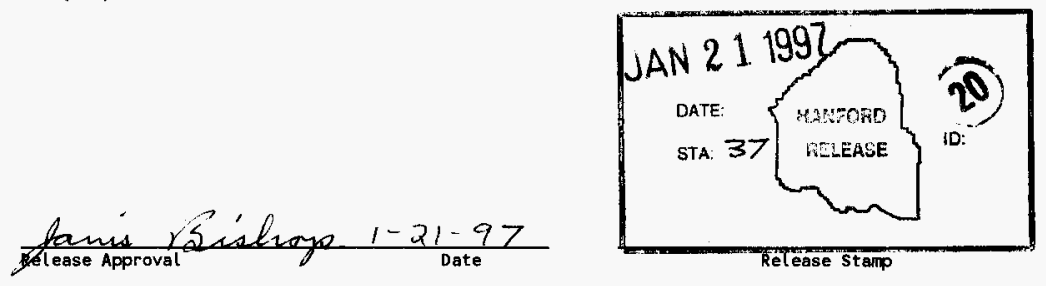

\section{Approved for Public Release}


(2) Title

TWRS Privatization Phase I Site Development Design Requirements Document

CHANGE CONTROL RECORO

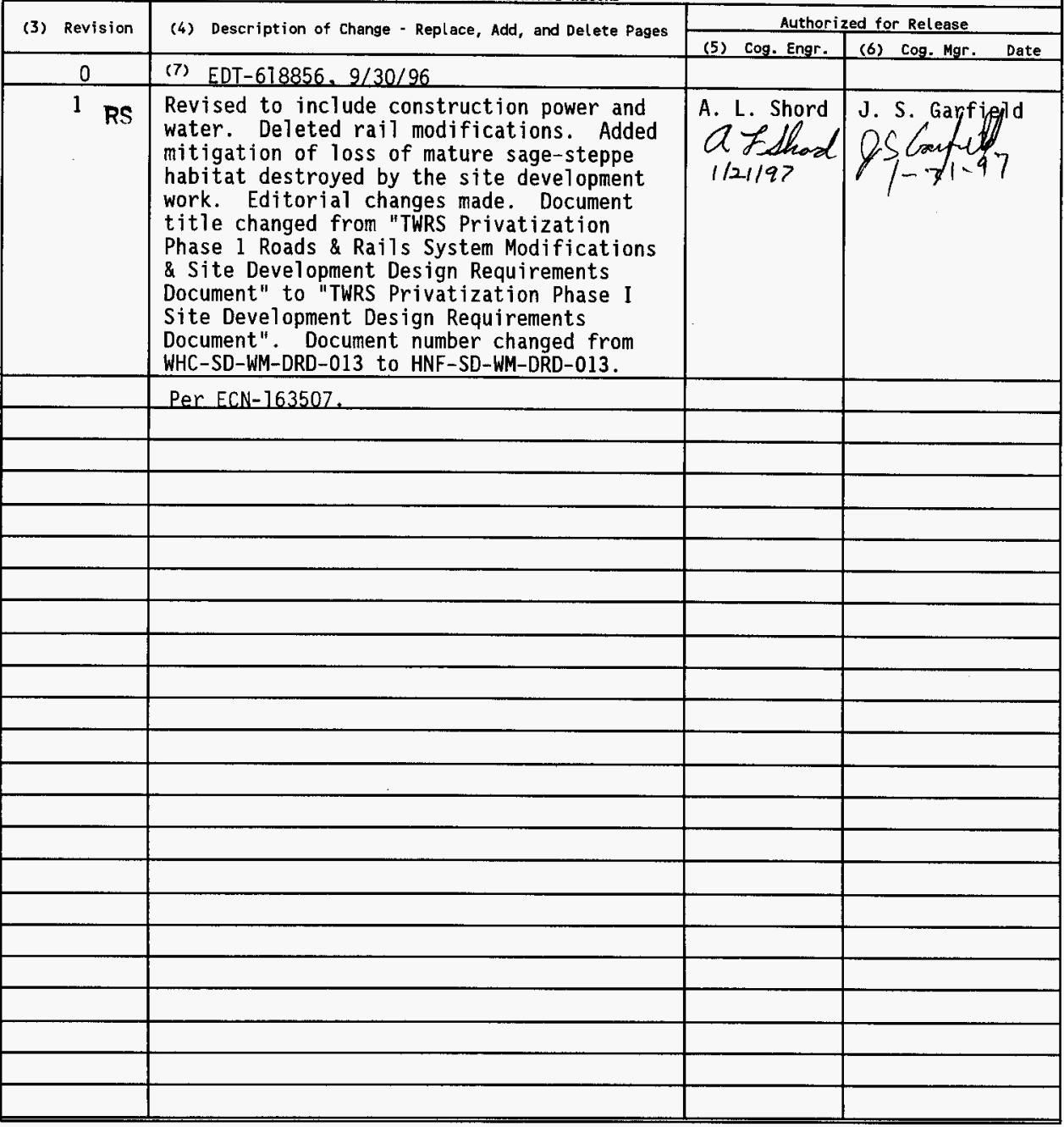


for

\title{
TWRS PRIVATIZATION PHASE I
}

\section{SITE DEVELOPMENT}

WORK ORDER E23387

\author{
Prepared for
}

Numatec Hanford Corporation

January 1997

Subcontract NHC-D-97-0005

Prepared by

Fluor Daniel Northwest

Richland, Washington 


\section{DESIGN REQUIREMENTS DOCUMENT}

for

\section{TWRS PRIVATIZATION PHASE I}

\section{SITE DEVELOPMENT}

WORK ORDER E23387

\section{Prepared by}

Fluor Daniel Northwest

Richland, Washington

for

Numatec Hanford Corporation

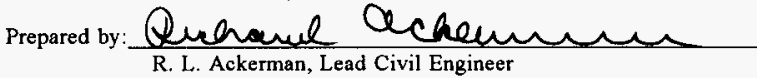

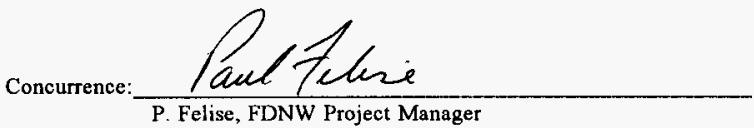




\section{TABLE OF CONTENTS}

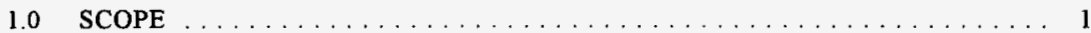

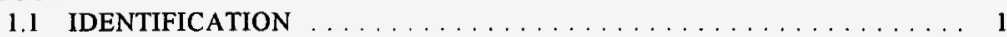

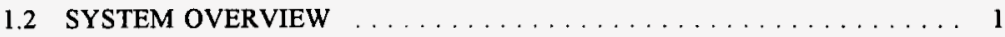

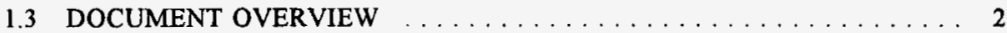

2.0 APPLICABLE DOCUMENTS $\ldots \ldots \ldots \ldots \ldots \ldots \ldots$

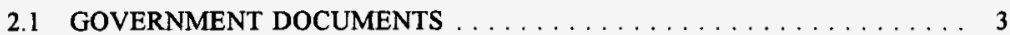

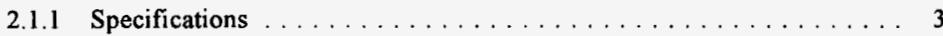

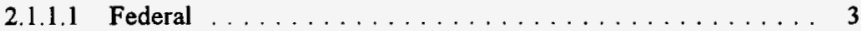

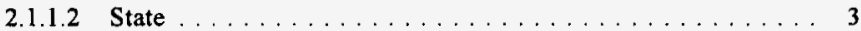

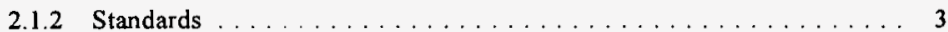

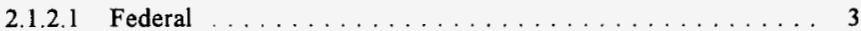

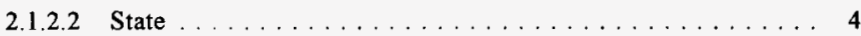

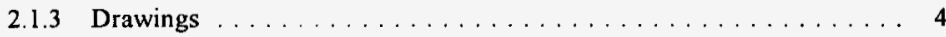

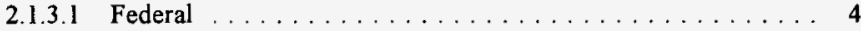

2.1.3.2 State .......................... 4

2.1 .4 Other Publications $\ldots \ldots \ldots \ldots \ldots \ldots \ldots \ldots \ldots \ldots \ldots$

2.1.4.1 Federal ....................... 4

2.1 .4 .2 State . . . . . . . . . . . . . . . . . . . 4

2.2 NON-GOVERNMENT DOCUMENTS $\ldots \ldots \ldots \ldots \ldots \ldots \ldots \ldots \ldots \ldots$

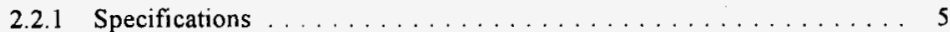

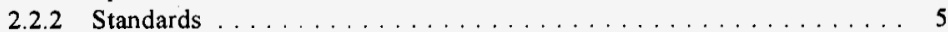

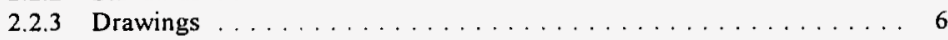

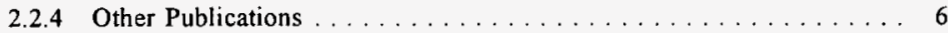

3.0 SYSTEM REQUIREMENTS $\ldots \ldots \ldots \ldots \ldots \ldots \ldots \ldots \ldots \ldots \ldots$

3.1 SYSTEM DEFINITIONS $\ldots \ldots \ldots \ldots \ldots \ldots \ldots \ldots \ldots \ldots$

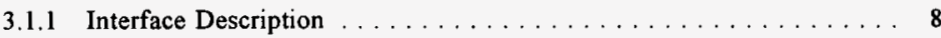

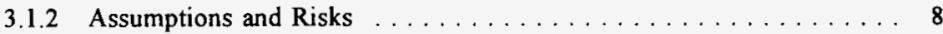

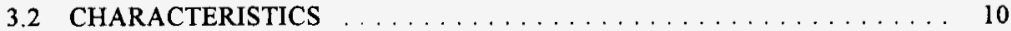

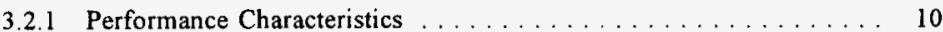

3.2 .2 System Capability Relationship . . . . . . . . . . . . . . . 10

3.2 .3 External Interface Requirements . . . . . . . . . . . . . 11

3.2.4 Physical Characteristics . . . . . . . . . . . . . . . . 11

3.2 .5 System Quality Factors . . . . . . . . . . . . . . . 11

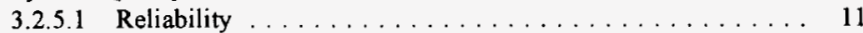

3.2.5.2 Maintainability. . . . . . . . . . . . . . . . . . . 11

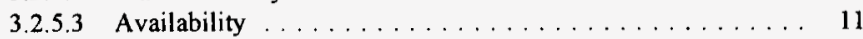

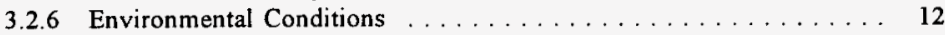

3.2 .7 Transportability . . . . . . . . . . . . . . . . . . 12

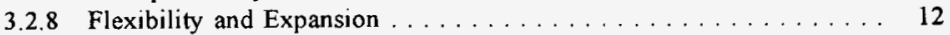




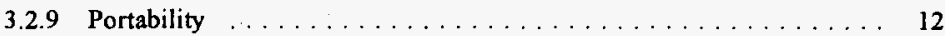

3.3 DESIGN AND CONSTRUCTION $\ldots \ldots \ldots \ldots \ldots \ldots \ldots \ldots \ldots, 12$

3.3.1 Materials ......................... 13

3.3 .2 Radiation .......................... 14

3.3.3 Name Plates and Product Markings . . . . . . . . . . . . . 14

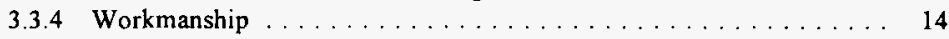

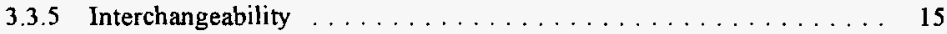

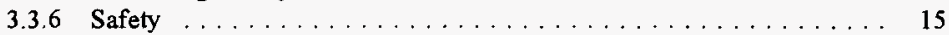

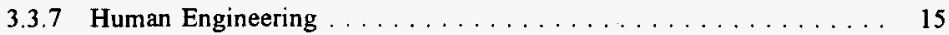

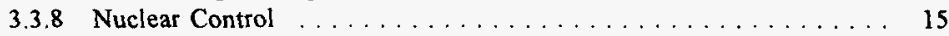

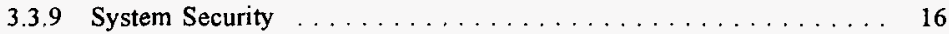

3.3.10 Government Furnished Property Usage . . . . . . . . . . 16

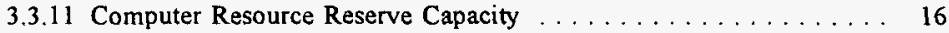

3.4 DOCUMENTATION $\ldots \ldots \ldots \ldots \ldots \ldots \ldots \ldots \ldots \ldots \ldots, 16$

3.4.1 Design Phase ......................... 16

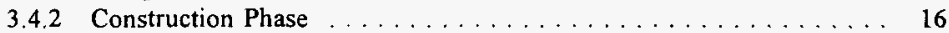

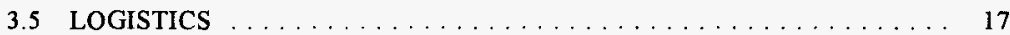

3.6 PERSONNEL AND TRAINING $\ldots \ldots \ldots \ldots \ldots \ldots \ldots \ldots \ldots \ldots \ldots$

3.7 CHARACTERISTICS OF SUB-SYSTEM ELEMENTS $\ldots \ldots \ldots \ldots \ldots, 17$

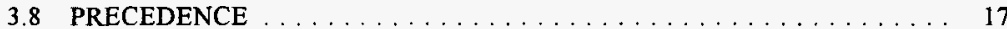

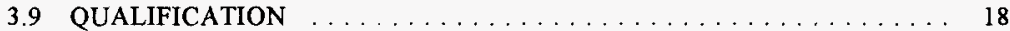

3.10 STANDARD SAMPLE $\ldots \ldots \ldots \ldots \ldots \ldots \ldots \ldots \ldots \ldots$

4.0 QUALITY ASSURANCE PROVISIONS $\ldots \ldots \ldots \ldots \ldots \ldots \ldots \ldots$

S.0 PREPARATION FOR DELIVERY $\ldots \ldots \ldots \ldots \ldots \ldots \ldots \ldots \ldots \ldots \ldots$

6.0 NOTES . . . . . . . . . . . . . . . . . . . 20

6.1 ABBREVIATIONS AND ACRONYMS $\ldots \ldots \ldots \ldots \ldots \ldots \ldots 20$

FIGURES

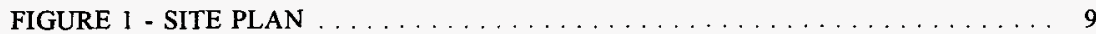




\title{
DESIGN REQUIREMENTS DOCUMENT
}

for

\author{
TWRS PRIVATIZATION PHASE I
}

SITE DEVELOPMENT

\subsection{SCOPE}

\subsection{IDENTIFICATION}

Design Requirements Document for TWRS Privatization Phase I Site Development.

\subsection{SYSTEM OVERVIEW}

The U.S. Department of Energy (DOE) has decided to privatize the treatment of most of the radioactive hazardous waste contained in the underground mixed waste storage tanks on the Hanford Site. Privatization is defined as vendors, under contract with DOE, using private funding to design, permit, construct, operate, and deactivate their own equipment and facilities to treat radioactive hazardous tank waste (or mixed waste as defined in the Washington Administrative Code [WAC] 173-303). Payment for these services takes the form of fixed price per unit of product meeting DOE specifications. Vendors are selected through a fixed-price competitive process.

Privatization activities have been divided into two phases. Phase $I$, a "proof of concept" phase, is to demonstrate the capabilities of privatization through the treatment of up to 13 percent of mixed waste at Hanford. Once demonstrated, privatization will be expanded into Phase II to include the treatment of the remainder of the waste.

In concert with the preparation of the Tank Waste Remediation System (TWRS) Request for Proposals (RFP), DE-RP06-96RL 13308 (RL, 1996) for the solicitation of privatization contractors, a location was selected for the Phase I facilities, WHC-SD-WM-SE023 (Shord, 1996). The location (the former grout disposal site) was selected for numerous reasons. Foremost: it was previously characterized and, to a degree, developed for the grout disposal program; it adjoins the planned feed tanks in the 200-East Area; and it is of sufficient size for two competing vendors to carry out the demonstration of pretreating and immobilizing mixed waste. The selected area will be parceled, and each privatization contractor (PC) will be assigned a site for development. 
This project is to prepare a portion of the former grout disposal site for turnover to the PC's for the construction of mixed waste facilities. The engineering study WHC-SD-TWRES-003 investigated various alternatives for site development. This study integrated engineering studies for Roads and Rail System Modifications, Raw and Potable Water Service, Liquid Effluent Transfer Systems and Electric Power to assure all the systems fit together. A separate letter report (Adhikari, 1996) identifies the preferred method for providing construction power. The Master Site Plan (WHC-SD-TWR-DSD-001) utilized the Site Development Engineering Study to assure privatization is fully integrated with other projects on the site.

This project will:

1. Set monuments that establish the boundaries for the two PC sites, and identify a construction lay down area for each PC. All work within each designated site and lay down area will be performed by the PC.

2. Prepare corridors for placement of the various utility systems and waste transfer lines. Preparation includes clearing and grubbing, removal of miscellaneous structures, and relocation of fences and gates.

3. Perform phased construction of the road system to support construction as detailed in Engineering Study WHC-SD-TWR-ES-004. This Engineering Study recommends using an existing siding for rail deliveries.

4. Provide construction power to the PC sites.

5. Provide raw water for construction activities.

6. Mitigate the loss of mature sage-steppe habitat destroyed by the development of the site roads, electrical substation, and utility corridors.

\subsection{DOCUMENT OVERVIEW}

This DRD will list the documents that form the basis for design and construction of the road modifications and site development. The documents will range from the general DOE and other Federal requirements applicable to all DOE sites to the more specific requirements applicable to the Hanford Site, and finally, to those specific to the applicable scope of work. 


\subsection{APPLICABLE DOCUMENTS}

\subsection{GOVERNMENT DOCUMENTS}

The following documents of the exact issue shown form a part of the specification to the extent specified herein. In the event of conflict between the documents referenced herein and the contents of this specification, the content of this specification shall be considered a superseding requirement.

\subsubsection{Specifications}

\subsubsection{Federal}

DOE Order 6430.1A, 1989, General Design Criteria, U.S. Department of Energy (DOE)

\subsubsection{State}

M 41-10,1994, Standard Specifications for Roads, Bridge and Municipal Construction, Washington State Department of Transportation (WSDOT).

M 22-01,1991, Design Manual, Washington State Department of Transportation (WSDOT).

M 41-01,1992, Construction Manual, Washington State Department of Transportation (WSDOT).

M 46-01,1988, Materials Branch Laboratory Manual, Washington State Department of Transportation (WSDOT).

\subsubsection{Standards}

\subsubsection{Federal}

Code of Federal Regulations:

29 CFR 1910, 1994, Occupational Safety and Health Standards.

29 CFR 1926, 1994, Safety and Health Regulations for Construction.

30 CFR 56, 1985, Safety and Health Standards-Surface Metal and Nonmetal Mines. 


\subsubsection{State}

WAC 173-303, 1994, Dangerous Waste Regulations, Washington Administrative Code.

WAC 296-45, 1994, Safety Standards, Electrical Workers, Washington Administrative Code.

\subsubsection{Drawings}

\subsubsection{Federal}

None Applicable

\subsubsection{State.}

M 21-01, 1993, Standard Plans for Road, Bridge and Municipal Construction, Washington State Department of Transportation (WSDOT).

\subsubsection{Other Publications}

\subsubsection{Federal}

DOE-RL-88-21, Rev. 3, 1994, Dangerous Waste Permit Application, 216-A-29 Ditch, U.S. Department of Energy, Richland Operations Office, Richland, Washington.

DE-RP06-96RL 13308, 1996, Request for Proposal, U.S. Department of Energy, Richland Operations Office, Richland, Washington.

\subsubsection{State}

None Applicable

Copies of specifications, standards, drawings and publications required by suppliers in connection with specified procurement functions should be obtained from the contracting agency or as directed by the contracting agent. 


\subsection{NON-GOVERNMENT DOCUMENTS}

The following documents of the exact issue shown form a part of this specification to the extent specified herein. In the event of conflict between the documents referenced herein and the contents of this specification, the contents of this specification shall be considered a superseding requirement.

\subsubsection{Specifications}

Hanford Electrical Utilities Distribution Specifications (Available from Hanford Electrical Utilities).

\subsubsection{Standards}

AASHTO, 1994, A Policy on Geometric Design of Highways and Streets, American Association of State Highway and Transportation Officials.

ANSI - American National Standards Institute,

ANSI/IEEE C2, 1997, National Electrical Safety Code.

ANSI C29.1, 1988, Electrical Power Insulators--Test Methods.

ANSI C29.2, 1992, Insulators Wet-Process Porcelain and Toughened Glass- Suspension Type.

ANSI C29.3, 1986, Wet-Process Porcelain Insulators--Spool Type.

ANSI C29.4, 1989, Wet-Process Porcelain Insulators--Strain Type.

ANSI C29.5, 1984, Wet-Process Porcelain Insulators--Low and Medium-Voltage Pin Type.

ANSI C29.6, 1984, Wet-Process Porcelain Insulators--High-Voltage Pin Type.

ANSI C29.8, 1985, Wet-Process Porcelain Insulators--Apparatus, Cap and Pin Type.

ANSI C29.9, 1983, Wet-Process Porcelain Insulators--Apparatus, Post Type.

ANSI/IEEE C62.11, 1993, Metal-Oxide Surge Arresters for Alternating Current Power Circuits 
ANSI C84.1, 1995, American National Standards for Voltage Ratings for Electrical Power Systems and Equipment.

ANSI D6.1, 1988, Manual on Uniform Traffic Control Devices for Streets and Highways. Also U. S. Department of Transportation, Federal Highway Administration, Part VI, 1993.

ANSI 05-1, 1992, Wood Poles - Specifications and Dimensions.

ANSI/IEEE C136 Series, 1994, Roadway Lighting Equipment.

ASTM B-232, 1992, Standard Specifications for Concentric-Lay-Stranded Aluminum Conductors, Coated Steel Reinforced (ACSR). American Society for Testing and Materials.

ASTM D-653, 1996, Standard Terminology Relating to Soil, Rock, and Contained Fluids, American Society for Testing and Materials.

IEEE - The Institute of Electrical and Electronic Engineers, Inc.

IEEE 751, 1990, Trial-Use Design Guide for Wood Transmission Structures .

IEEE C135 Series, 1995, Pole Line Hardware Standards Collection.

IES HB-93, 1993, Lighting Handbook Application and Reference Volume, Illuminating Engineering Society of North America.

NEMA LA1, 1992, Surge Arresters, National Electrical Manufacturers Association.

NFPA Article 70, 1996, National Electrical Code, National Fire Protection Association.

\subsubsection{Drawings}

None Applicable

\subsubsection{Other Publications}

WHC-SD-WM-SP-011, 1996, Solidified High-Level Waste Interim Storage Alternative Analysis and Path Foreword Recommendation, Calmus, R.B.

WHC-SD-W465-AGA-001, 1996, Alternatives Generation and Analysis Report for Immobilized Low-Level Waste Interim Storage Architecture, Burbank, D. A. 
Interoffice Memorandum, 1996, Tank Waste Remediation System Privatization Phase I, Former Grout Disposal Site Vendor Site Layout and Access Road Assessment Report, Trost, E.T.

WHC-SD-WM-SE-023, 1996, Tank Waste Remediation System Privatization Phase I Site Evaluation Report, Shord, A.L.

WHC-SD-TWR-ES-002, 1996, Engineering Study, TWRS Privatization Phase I, Raw and Potable Water Service, Fort, D.L.

WHC-SD-WM-DRD-015, 1996, Design Requirements Document for TWRS Privatization Phase I, Raw and Potable Water Service, Gaddis, L.A.

WHC-SD-WM-ES-396, 1996, Engineering Study, Privatization Phase I, Liquid Effluent Transfer Systems, Palit, A.N.

WHC-SD-TWR-ES-004, 1996, Engineering Study, TWRS Privatization Phase I, Roads and Rail System Modifications, Ackerman, R.L.

WHC-SD-TWR-ES-003, 1996, TWRS Privatization Phase I, Site Development Engineering Study, Fort, D.L.

WHC-SD-WM-ES-393, 1996, Engineering Study for the Phase I Privatization Facilities Electrical Power, Singh, G.

WHC-SD-TWR-DSD-001, 1996, TWRS Privatization Phase I Master Site Plan, Trost,E.T.

PNNL-1107, UC-603, 1996, Climatological Data Summary 1995 with Historical Data, Hoitink, D. J., Pacific Northwest National Laboratory, Richland, Washington.

Akerson, A.W., Report, 1996, Phase I Privatization Project Construction Power Estimates (A Review of Past Hanford Site Large Scale Construction Project Power Requirements), Parsons Infrastructure And Technology Group, Inc., Richland, Washington.

Adhikari, R. Report, 1996, 13.8 KV Construction Power for Phase I Privatization Facilities, ICF Kaiser Hanford Company, Richland, Washington.

WHC-SD-WM-ICD-037, 1996, Interface Control Document for Land for Siting.

Technical society and technical association specifications and standards are generally available for reference from libraries. They are also distributed among technical groups and federal agencies. 


\subsection{SYSTEM REQUIREMENTS}

\subsection{SYSTEM DEFINITIONS}

\subsubsection{Interface Description}

The site plan as shown by Figure 1 depicts interfaces for the roads and the LAW and HLW corridors. Figure 1 also shows locations of construction water standpipe and indicates raw water loop adjacent to each PC site. Also shown is the $13.8 \mathrm{kV}$ construction electric power to be supplied to the PC site boundaries.

The construction electrical power will be provided from the existing $13.8 \mathrm{kV}$ switchgear located at $25 \mathrm{l}-\mathrm{W}$ (A8) substation in the 600 Area (approximately $2 \mathrm{~km}$ north of the 200-West Area). A major portion of the distribution feeders (C8L6 and C8L5) from 251-W already exists (Adhikari, 1996). The PC will provide cabling from the last electrical pole to its distribution center. A primary utility-grade energy metering device will be provided at the delivery/interface point of each PC. Protective relaying and isolation devices of the PC distribution system shall be coordinated with the utility $13.8 \mathrm{kV}$ system.

\subsubsection{Assumptions and Risks}

The two PC sites will be located substantially as shown in Figure 1. Because of the relatively large areas of each PC site, 6.08 Hectares (15 Acres), the presence of the existing grout vaults, the possibility of new vault(s) being constructed close to the PC sites, the requirements that the sites be as close to the AP Tank Farm feed tanks as possible and the need for level sites there is not much chance that the sites will be changed from that shown. See TWRS Privatization Phase I Site Development Engineering Study, WHC-SD-TWR-ES003, for a discussion and recommendations on the location of the PC sites.

Construction power will be provided to the PC sites. Each PC will negotiate cost and schedule for receiving power from the existing $13.8 \mathrm{kV}$ system. It is assumed that PC construction electric power needs will not exceed $4 \mathrm{MW}$ for each site (8 MW total).

It is assumed that an embankment for a road and utility crossing of the 216-A-29 Ditch can be constructed. As the ditch is an inactive unit permitted under RCRA, there are uncertainties and risks associated as to the level of effort that must be employed to satisfy the issues and concerns of the regulatory authorities. 


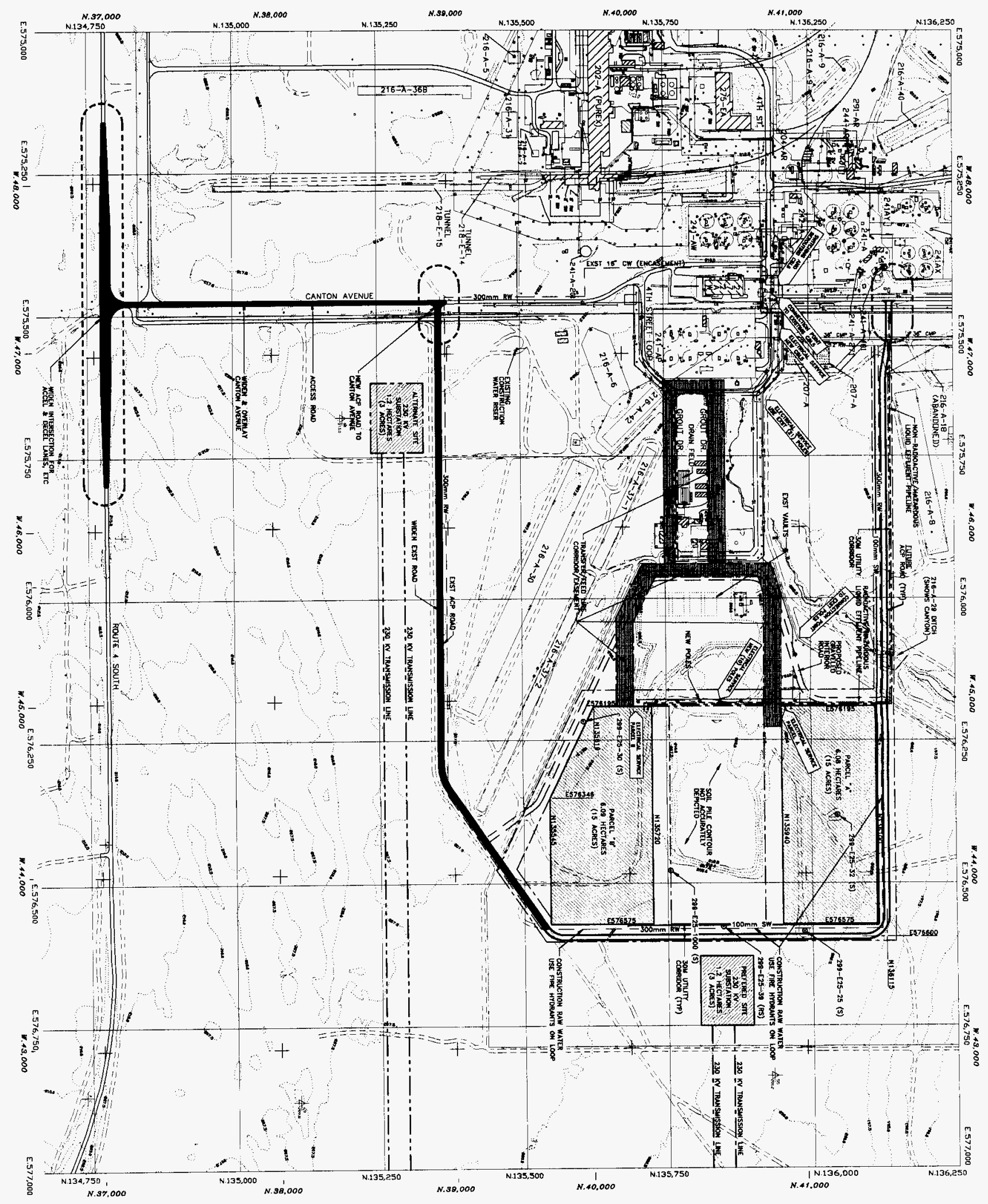

000 政籍管

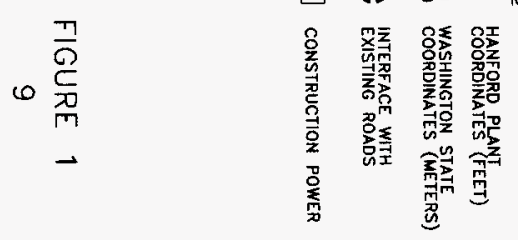

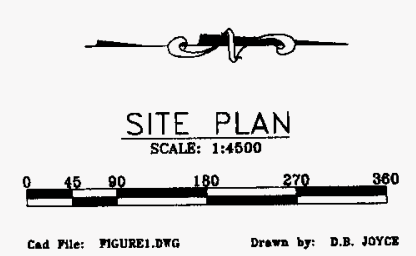




\subsection{CHARACTERISTICS}

\subsubsection{Performance Characteristics}

Roads must connect with the existing network, be available at all times, handle the traffic volume safely, and be designed for size and weight of all vehicles expected. Route $4 \mathrm{~S}$ and the remainder of the state road system allow legal loads up to $36,300 \mathrm{~kg}(80,000 \mathrm{lbs}$.). Heavier loads are allowed with permits. Loads up to $45,400 \mathrm{~kg}(100,000 \mathrm{lbs}$.) can be allowed on the improved and new roads as long as the speeds are kept low. Over width and height loads can be permitted with traffic control.

Site development must assure that all the systems needed to serve the PC sites are integrated with each other. Also, site development must assure the corridors necessary for product feed lines, roads, and utilities are established and graded as required.

The modifications and extensions to the existing 200 East Area $13.8 \mathrm{kV}$ power distribution system are to maintain the integrity of the existing system and be capable of delivering up to $4 \mathrm{MW}$ to each $\mathrm{PC}$ site. The service voltage at the $\mathrm{PC}$ site boundary will be within the limits established in ANSI C84.1. New protective relaying and isolation devices shall be coordinated with the existing system.

Construction raw water for site development will be supplied initially from the existing standpipe southwest of the grout disposal site. After installation of the raw water system extension (see Engineering Study WHC-SD-TWR-ES-002 and Design Requirements Document WHC-SD-WM-DRD-015), which should be prior to the start of PC construction activities, construction water can be obtained at various fire hydrants that will be located throughout the site.

\subsubsection{System Capability Relationship}

For construction power, a design analysis shall be performed to demonstrate that addition of construction loads will not cause unacceptable overload, under voltage or any other transient conditions at the existing system buses. If necessary, voltage correction devices will be provided.

For construction water, a design analysis shall be performed to demonstrate that construction water demands will not cause unacceptable impacts to the raw water distribution system. To prevent unacceptable pressure drops/spikes in the distribution system, flow limiting devices shall be employed to restrict the flow of water to that identified by the analysis but no more than $750 \mathrm{lpm}(200 \mathrm{gpm})$. In addition, shut off or control valves shall be slow closing (no butterfly or ball valves). 


\subsubsection{External Interface Requirements}

Roads must connect with the existing network, and be located and configured for safe access, with minimal effect on existing traffic.

Site development must rely on the Master Site Plan to ensure the external interfaces are correct. The Master Site Plan will also ensure the external interface for the product lines will be compatible with the PC sites.

\subsubsection{Physical Characteristics}

Inherent in the layout for roads are the location of connections to the existing network, topography of selected routes, design of pavement cross sections and use of native materials to meet the design traffic requirement.

Site development requires that the layout of PC sites must be of sufficient size, the grade must be nearly level and operations at each site must have a minimal effect on the other PC site.

The existing $13.8 \mathrm{kV}$ distribution lines, poles and switchgear will be utilized as much as practicable for construction power. Routing of new distribution lines will avoid contaminated areas and be approved by Hanford Site Utilities.

\subsubsection{System Quality Factors}

3.2.5.1 Reliability. As long as routine maintenance is performed as required, reliability of road and site development should be high.

3.2.5.2 Maintainability. The road network requires routine maintenance, such as inspection, minor patching, debris and snow removal, shoulder grading, weed spraying and stripe and sign maintenance. Periodic maintenance for the roads will probably require some sort of chip seal every five or six years.

Site development maintenance should be simple, consisting mainly of weed control.

3.2.5.3 Availability. As noted in the two sections immediately above, with proper design, construction and on-going maintenance, road systems should be available nearly full time with only minor inconvenience to users during maintenance activities. Alternative roads will be available if any one road needs to be shut down for any reason. 


\subsubsection{Environmental Conditions}

Road design and construction practices are based on assuring the road system is compatible with the expected environment for the life of the system.

Climatological data from Climatological Data Summary 1995 with Historical Data, PNNL, 1996 along with WSDOT Design Manual, will be used to design roads, site development and construction power for expected environmental conditions.

\subsubsection{Transportability}

Not applicable.

\subsubsection{Flexibility and Expansion}

Once road corridors are established outside the boundary of the Grout Disposal Site there should be little reason to change routes or geometry. A two lane road should easily handle all projected traffic volumes. Road systems inside the Grout Disposal Site may have to be adjusted if either or both of the PC alters its site significantly, but there should be enough room to accommodate such change.

\subsubsection{Portability}

Not applicable.

\subsection{DESIGN AND CONSTRUCTION}

For site development, DOE Order 6430.1A, General Design Criteria, specifies in section 0200-1.l a number of factors that must be considered in developing a site. These factors were considered when the site for Privatization Phase I was chosen.

The scope of site development is limited to designating the two sites for the PC, surveying to establish the boundaries for the selected sites, site grading and earthwork outside the PC sites, development of corridors for LAW and optional HLW feed lines to the PC sites and integration of utilities and transportation corridors. Surveying is covered by section 0202 of $6430.1 \mathrm{~A}$, demolition by section 0205 and site preparation by section by 0210 . 
The PC will have the responsibility to design and construct the facilities inside their respective sites. This DRD will not reference sections of $6430.1 \mathrm{~A}$ that relate to the scope of work by the PC.

For roads, Section 0250-3 of 6430.1 A specifies geometry and gradients be designed in accordance with American Association of State Highway and Transportation Officials (AASHTO) GDHS-84, which is now obsolete, and has been superseded by A Policy on Geometric Design of Highways and Streets AASHTO. Pavements design is specified to conform with local State highway department standards (6430.1 A, 0250-5), which would be Washington State Department (WSDOT), Standard Specifications for Road, Bridge and Municipal Construction, M 41-10-94, and WSDOT Design Manual, M 22-01. Signing, pavement markings and channelization shall comply with the Manual on Uniform Traffic Control Devices for Sireets and Highways, ANSI 6.1 and DOE Order 6430.1A. Roadway lighting shall comply with IES Lighting Handbook HB-93 and ANSI C 136 series. Electrical installation related to traffic control devices and roadway lighting shall be in accordance with National Electrical Code, NFPA-70.

Design and construction of the construction electric power system shall conform to DOE Order 6430.1A, Division 16 and National Electric Safety Code, ANSI/IEEE C2.

\subsubsection{Materials}

For roads and miscellaneous site grading, materials shall consist of native and imported materials meeting the following WSDOT specifications:

9-02 Bituminous Materials

9-05 Drainage Structures, Culverts and Conduits

9-14 Erosion Control and Roadside Planting

9-16 Fence and Guardrail

9-28 Signing, Materials and Fabrication

9-29 Illumination, Signing, Electrical

For construction electrical power, selection of electrical materials shall be coordinated with Hanford Electrical Utilities Specifications (available from Hanford Electrical Utilities).

Wooden structures for pole lines to be in accordance with ANSI 05.1, shall be used to support the overhead distribution conductors. Guys will be provided for wooden structures subject to forces in excess of their strength, such as structures in dead-end or heavy angle positions, and for other structures where required rigidity cannot be economically obtained by a self-supporting design. The wooden structures and necessary hardware shall be in accordance with IEEE C135 and IEEE 752. 
Insulators shall be designed so that the ratio of their low-frequency dry flash over voltage to low-frequency puncture voltage is in conformance with applicable ANSI Standards C29.1 through C29.9.

The current rating of the conductors shall be adequate to serve the highest anticipated load without resulting in unsatisfactory voltage regulation. Overhead lines shall be bare aluminum conductor steel reinforced (ACSR) ANSI/ASTM B 232. The conductor shall be strung using tension stringing methods only, in accordance with manufacturer's recommendations.

Interconnection terminals at overhead line interface points shall be compatible with the $\mathrm{PC}$ provided cables.

Clearances for the supply lines shall be in accordance with ANSI/IEEE C2 to ensure safety.

Surge arresters may be needed, if so shall meet the requirements of NEMA LA1 and ANSI/IEEE C62.11.

Switches shall be gang operated, load break type disconnect switches.

Tie-in to PC distribution systems shall use details to conform to existing site utilities. The new design shall ensure matching corresponding properties at the tie-in point.

\subsubsection{Radiation}

Not applicable

\subsubsection{Name Plates and Product Markings}

For construction power, equipment and any parts of that equipment to be used by personnel shall be identified with appropriate labels. (Electrical equipment numbers will be provided by Hanford Electrical Utilities.)

\subsubsection{Workmanship}

For roads, the following WSDOT sections of 1994 Standard Specification apply:

2.01 Clearing and Grubbing and Roadside Cleanup

2.03 Roadway Excavation and Embankment 


\subsection{Haul \\ 2.06 Subgrade Preparation \\ 2.07 Watering \\ 2.09 Structural Excavation \\ 4.02 Gravel Bases \\ 4.04 Ballast and Crushed Surfacing \\ 5.04 Asphalt Concrete Pavement \\ 7.02 Culverts \\ 8.01 Erosion Control \\ 8.11 Guardrail \\ 8.20 Illumination, Traffic Signals and Electrical \\ 8.21 Permanent Signing \\ 8.22 Pavement Markings}

For site development, see the applicable sections for roads above.

\subsubsection{Interchangeability}

For construction power, new system components shall be interchangeable with the existing system components.

\subsubsection{Safety}

Safety reviews performed during the normal planning, design and execution of the roads and site development will mitigate identified hazards associated with construction and operations. All construction shall be in accordance with appropriate safety codes, regulations and standards.

For construction electrical power the system shall be designed and installed in accordance with DOE Order 6430-1A, the National Electric Safety Code IEEE C2, and WAC 296-45.

\subsubsection{Human Engineering}

Not applicable.

\subsubsection{Nuclear Control}

Not applicable. 


\subsubsection{System Security}

Not applicable.

\subsubsection{Government Furnished Property Usage}

Selected on-site areas or previously developed pits will be identified for the site development contractors' use in obtaining sources of fill soils, sand, and gravel for site development, earthwork, and stabilization, and base material for roads.

\subsubsection{Computer Resource Reserve Capacity}

Not applicable.

\subsection{DOCUMENTATION}

\subsubsection{Design Phase}

Initial documentation required would be to record the baseline for the project- technical, cost and schedule. Technical baseline would be as outlined in Sections 3.3, 3.3.1 and 3.3.4, with additional details in a Conceptual Design Report, as required. Cost and schedule baseline would integrate the technical requirements and other requirements that establish a schedule when the road and site development must be complete to meet the requirements of the PC.

Once the baseline is established, progress reports comparing progress to the baseline would be issued periodically. These reports would also document adherence with the established technical requirements. Documents required to actually accomplish the work in the field, i.e. Procurement Specifications, Drawings, Calculations and Construction Specifications, would be checked and reviewed in accordance with requirements established by the baseline. Then, the documents would be released for construction. Document control during the entire design and construction phases would be per Hanford Site standards.

\subsubsection{Construction Phase}

Much of the documentation required during the construction phase is related to the business side - progress payments, claims, safety reporting and the like. Documentation related to assuring the construction is completed in accordance with specifications includes 
submittal by the contractor for approval by the contract administrator, quality assurance records (see Section 4.0) and periodic reports by the contract administrator. Records of engineering changes during construction track the changes to the original design. Finally, asbuilding when the project is complete would record the final configuration.

\subsection{LOGISTICS}

See below for consideration of various factors:

1. Maintenance- See Section 3.2.5.2.

2. Transportation Modes- Not applicable.

3. Supply-system requirements- Not applicable.

4. Impact on existing facilities- See Section 3.2.3.

5. Impact on existing equipment- See Section 3.2.2.

\subsection{PERSONNEL AND TRAINING}

No additional personnel or special training should be required to operate and maintain the roads or the developed site, since the changes are simply additions to existing facilities.

\subsection{CHARACTERISTICS OF SUB-SYSTEM ELEMENTS}

Not applicable.

\subsection{PRECEDENCE}

The hierarchial relationship of documents is as follows:

Federal Laws - Code of Federal Regulations.

Revised Code of Washington (RCW), as applied in the Washington Administrative Code (WAC).

Local Ordinances

US DOE Orders. Particularly DOE 6430.1A. 
Washington State Standard Specifications.

National Codes (ASTM, ANSI, etc.).

\subsection{QUALIFICATION}

Not applicable

\subsection{STANDARD SAMPLE}

Not applicable 


\subsection{QUALITY ASSURANCE PROVISIONS}

The following matrix shows the important quality assurance requirements for roads and site development and construction electrical power:

\begin{tabular}{|c|c|c|c|}
\hline Specification & Description & Responsibility & Remarks \\
\hline $\begin{array}{l}\text { WSDOT } \\
2.03,9.02,9.04\end{array}$ & $\begin{array}{l}\text { Asphalt Concrete } \\
\text { Pavement }\end{array}$ & Engineer & $\begin{array}{l}\text { Approve mix before } \\
\text { placing. }\end{array}$ \\
\hline $\begin{array}{l}\text { ICF KH } \\
\text { Procedures }\end{array}$ & Backfill Permit & Engineer & $\begin{array}{l}\text { To Contractor before } \\
\text { backfill begins. }\end{array}$ \\
\hline $\begin{array}{l}\text { WSDOT } \\
9.02,5.04\end{array}$ & $\begin{array}{l}\text { Initial Crack } \\
\text { Sealing }\end{array}$ & Engineer & $\begin{array}{l}\text { Approve before work } \\
\text { begins }\end{array}$ \\
\hline $\begin{array}{l}\text { WSDOT } 9.02 \text {, } \\
5.04\end{array}$ & $\begin{array}{l}\text { Lab Test, ACP } \\
\text { Mixture }\end{array}$ & Contractor & $\begin{array}{l}\text { Submit to engineer for } \\
\text { approval. }\end{array}$ \\
\hline $\begin{array}{l}\text { WSDOT } \\
9.02,5.04\end{array}$ & $\begin{array}{l}\text { Paving, verify } \\
\text { temp.,tack coat, } \\
\text { compaction. }\end{array}$ & Contractor & Records to Engineer. \\
\hline WSDOT 2.03 & $\begin{array}{l}\text { Backfill } \\
\text { Compaction }\end{array}$ & Contractor & $\begin{array}{l}\text { Test results record to } \\
\text { Engineer. }\end{array}$ \\
\hline $\begin{array}{l}\text { WSDOT } \\
4.02,4.04 \\
\end{array}$ & Base Compaction & Contractor & $\begin{array}{l}\text { Test results record to } \\
\text { Engineer. }\end{array}$ \\
\hline $\begin{array}{l}\text { WSDOT } \\
4.02,4.04\end{array}$ & Density of base & Contractor & $\begin{array}{l}\text { Test results record to } \\
\text { Engineer. }\end{array}$ \\
\hline $\begin{array}{l}\text { WSDOT } 4.02 \text {, } \\
4.04\end{array}$ & Gradation & Contractor & $\begin{array}{l}\text { Test result record to } \\
\text { Engineer. }\end{array}$ \\
\hline $\begin{array}{l}\text { IEEE C2 and } \\
\text { WAC 296-45 }\end{array}$ & $\begin{array}{l}\text { National Electrical } \\
\text { Safety Code }\end{array}$ & Contractor & $\begin{array}{l}\text { Inspection/ Test Results } \\
\text { Records to Engineer }\end{array}$ \\
\hline NFPA-70 & $\begin{array}{l}\text { National Electrical } \\
\text { Code }\end{array}$ & Contractor & $\begin{array}{l}\text { Inspection/ Test Results } \\
\text { Records to Engineer }\end{array}$ \\
\hline
\end{tabular}




\subsection{PREPARATION FOR DELIVERY}

Not applicable.

\subsection{NOTES}

\subsection{ABBREVIATIONS AND ACRONYMS}

AASHTO American Association of State Highway and Transportation Officials

ACSR Aluminum Conductors, Coated Steel Reinforced

ANSI American National Standards Institute

ASTM American Society for Testing and Materials

DOE U. S. Department of Energy

DRD Design Requirements Document

HLW High Level Waste

IEEE The Institute of Electrical and Electronic Engineers, Inc.

LAW Low Activity Waste

NEMA National Electrical Manufacturers Association

PC Privatization Contractor(s)

RL U. S. Department of Energy, Richland Operations Office

TWRS Tank Waste Remediation System

WHC Westinghouse Hanford Company

WAC Washington Administrative Code

WSDOT Washington State Department of Transportation 


\section{DISTRIBUTION SHEET}

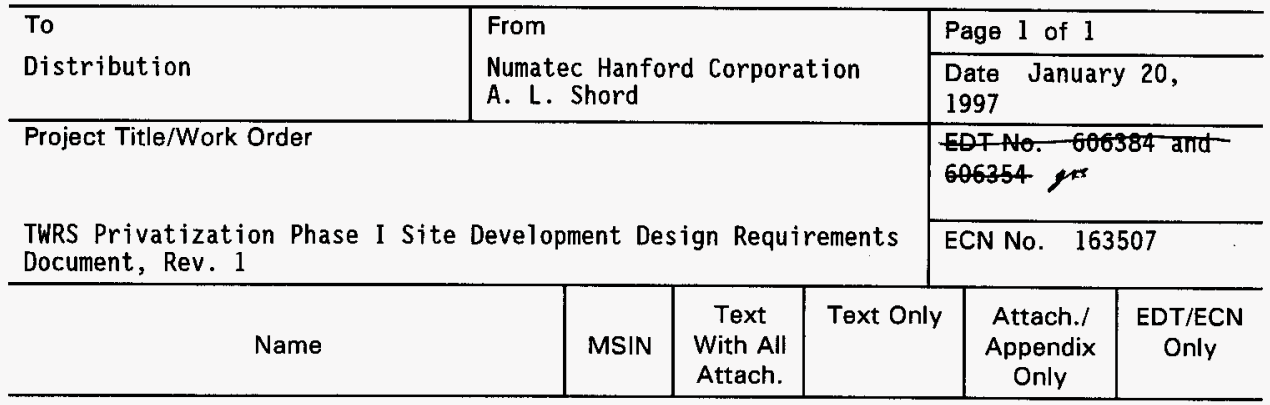

U.S. Department of Energy

Richland Operations office

N. R. Brown

R. A. Gilbert

T. R. Hoertkorn

D. J. Ortiz

W. A. Rutherford

R. B. Simmons-Green

N. L. White

Lockheed Martin Hanford Corporation

M. N. Islam

P. C. Miller

R. W. Powell

Numatec Hanford Corporation

T. Choho

J. S. Garfield

R. J. Parazin

G. Singh

A. L. Shord (5)

Fluor Daniel Northwest

R. L. Ackerman

P. Felise

D. L. Fort

J. L. Henderson

Pacific Northwest National Laboratory
K6-51

K6-51

B4-55

A2- 45

A2-45

S7-53

B4-55 $x$
$x$
$x$
$x$
$x$
$x$
$x$

S5-12

R1-51

G3-21

$x$

$x$

$X$

H5-61 X

H5-49 $X$

H5-49 $X$

H6-11 $X$

H5-49 $X$
B. A. Reynolds
P7-19
$X$

DynCorp Tri-Cities Services Incorporated
E. F. Yancey
G3-07
$x$
Central Files (original +1 )
A3-88
$\mathrm{X}$ 